\title{
Radiofrequency obliteration to treat the great saphenous vein insufficiency, an option in geriatrics patients
}

\author{
B Bonfiglio,, G Dipaola, G Navarra \\ From de Senectute: Age and Health Forum \\ Catanzaro, Italy. 5-7 December 2009
}

\section{Background}

Radiofrequency (RF) ablation of Great Saphenous Vein (GSV) without high ligation, using controlled-heating to close vein. A minimally invasive treatment alternative to conventional surgery represents a valid option for geriatrics patients with venous insufficiency.

\section{Materials and methods}

From 2001 to 2007, 123 patients 62-86 y.o. (average 74), with GSV insufficiency, selected through ultrasound examination according to the features of GSV: duration reflux longer 1"; diameter between 5 and $12 \mathrm{~mm}$;

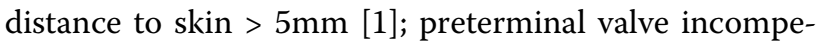
tent, terminal valve competent, regular path and bore. Patients were not affected by severe leg arteriopathy $(A B I \geq 1)$. The operation was performed in day surgery and local anesthesia. For 42 (34\%) saphenous diameter sized between 5-8 mm, used 6F catheters, other $81(66 \%)$ between $8-12 \mathrm{~mm}$, used $8 \mathrm{~F}$ catheters. Intraoperative ultrasound examination performed to control the catheter position (Figure 1), also after procedures to confirm vein occlusion and saphenous-femoral junction patency. Then compressive-elastic stocking was applied and they were discharged after 2 hours and returned to normal activity after 24-36 hours.

\section{Results}

All patients had slight post-operative pain in the path of the treated saphenous segment, disappearing in 5-7 days. They have been clinically checked after 3 and 6 days and with duplex-scanned after 30 days, 6 months, 1 and 2 years. Elastic-compression stocking was

\footnotetext{
Phlebology and Wound Care, Surgical Department, University Hospital,
} Messina, Italy

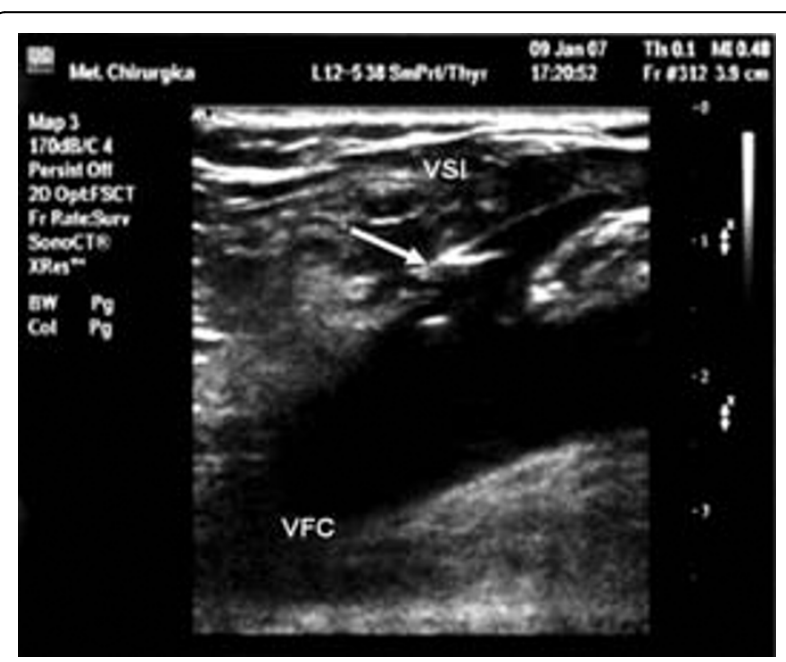

Figure 1

removed after 3 days. Only 5(4\%) patients had little haematomas in the surgical incision site, disappeared in 7-10 days, 2 (2\%) patients had paresthesia. Duplex scanning showed one recanalization (1\%), other veins were fibrotic 1 month later and 6 months later they were completely sclerosed and barely visible as a weak hyperecogenic signal (Figure 2). GSV persistent occlusion and reflux-free was documented in 122/123 (98\%) at 1 year, $113 / 123(92 \%)$ at 2 years follow-up. Neither thrombosis nor thermal injury were observed, paresthesia persisting in $2(2 \%)$ at 1 year and $1(1 \%)$ at 2 year follow-up.

\section{Conclusions}

RF treatment is more appreciated, especially by elderly, because it is minimally invasive allowing immediate discharge, rapid return to normal activity, mild pains. 


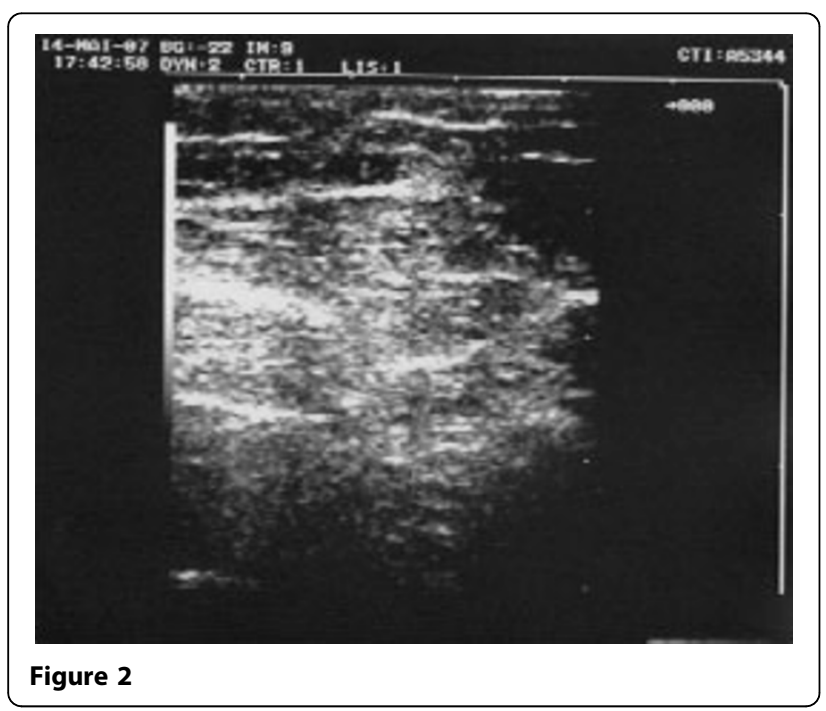

It represents a valid option in geriatrics patients with venous insufficiency. However, a correct selection of patients is necessary on accurate studying of features of GVS, excluding arteriopaty and pacemaker. RF treatment causes permanent closure of GSV, showing lasting over time efficacy, without the morbidity and longer convalescence associated with conventional surgical vein ligation and stripping [2] but results depend on careful execution of procedure.

\section{Published: 19 May 2010}

\section{References}

1. Dipaola G, Venneri A, Bonfiglio B, Navarra G: Radiofrequency Obliteration to Treat the Great Saphenous Vein Insufficiency: Long-Term Results. Eur Surg Res 2008, 41:59-196.

2. Lurie F, Creton D, Eklof B, Kabnick LS, Kistner RL, Pichot O, Sessa C, SchullerPetrovic S: Prospective randomised study of endovenous radiofrequency obliteration (closure) versus ligation and vein stripping (EVOLVeS): two-year follow-up. Eur J Vasc Endovasc Surg. 2005, 29.

doi:10.1186/1471-2318-10-S1-A43

Cite this article as: Bonfiglio et al:: Radiofrequency obliteration to treat the great saphenous vein insufficiency, an option in geriatrics patients. BMC Geriatrics 2010 10(Suppl 1):A43.

\section{Submit your next manuscript to BioMed Central} and take full advantage of:

- Convenient online submission

- Thorough peer review

- No space constraints or color figure charges

- Immediate publication on acceptance

- Inclusion in PubMed, CAS, Scopus and Google Scholar

- Research which is freely available for redistribution

Submit your manuscript at www.biomedcentral.com/submit 